\title{
THE EMBEDDEDNESS OF SOCIAL ENTREPRENEURSHIP: UNDERSTANDING VARIATION ACROSS LOCAL COMMUNITIES
}

\author{
Christian Seelos \\ Johanna Mair \\ Julie Battilana \\ M. Tina Dacin
}




\title{
THE EMBEDDEDNESS OF SOCIAL ENTREPRENEURSHIP: UNDERSTANDING VARIATION ACROSS LOCAL COMMUNITIES
}

\author{
Christian Seelos' \\ Johanna Mair ${ }^{2}$ \\ Julie Battilana ${ }^{3}$ \\ M. Tina Dacin ${ }^{4}$
}

\section{Abstract}

Social enterprise organizations (SEOs) arise from entrepreneurial activities with the aim of achieving social goals. SEOs have been identified as alternative and/or complementary to the actions of governments and international organizations to address poverty and poverty-related social needs. Using a number of illustrative cases, we explore how variation of local institutional mechanisms shapes the local "face of poverty" in different communities and how this relates to variations in the emergence and strategic orientations of SEOs. We develop a model of the productive opportunity space for SEOs as a basis of and an inspiration for further scholarly inquiry.

\footnotetext{
${ }^{1}$ Senior Lecturer, Strategic Management, IESE

${ }^{2}$ Associate Professor, Strategic Management, IESE

${ }^{3}$ Harvard Business School

${ }^{4}$ Queen's School of Business
} 


\section{THE EMBEDDEDNESS OF SOCIAL ENTREPRENEURSHIP: UNDERSTANDING VARIATION ACROSS LOCAL COMMUNITIES}

\section{Introduction}

The World Bank has dedicated its 1990 annual development report to the poor in the least developed countries (The World Bank, 1990). The authors view poverty from the dual perspectives of income as a comparative measure and of concrete poverty-related social needs such as health, literacy or access to food. Poverty, whether measured in terms of income levels or wealth levels, persists in important and intolerable dimensions (Davies, Sandström, Shorrocks, and Wolff, 2008; Chen and Ravallion, 2007). Substantial amounts of development funds are allocated to meet poverty and poverty-related social needs (OECD, 2009), yet the stubborn persistence of poverty implies that traditional development initiatives of governments and international organizations fail to achieve their objectives.

A consensus is emerging on the limits of large scale economic development programs. These programs overly privilege western style institutions, practices, and reliance on free markets, without paying adequate attention and respect to the local institutions (Fowler, 2000; Rodrik, 2007). Too often they fail to "trickle down" to make a difference to the poor in local communities or they fail to address the root causes of the social ills they aim to address (Easterly, 2006; Peredo and Chrisman, 2006).

Over the last decade, scholars have highlighted the phenomenon of a particular form of local entrepreneurship that explicitly targets poverty or the social needs associated with poverty (Seelos and Mair, 2005; Mair and Martí, 2006). Social entrepreneurship is an emerging umbrella-term for this phenomenon and encompasses a variety of organizational innovations that target diverse social and environmental challenges. In this paper we are primarily interested in social entrepreneurial activities that build organizations that address the different "faces of poverty," i.e., the local characteristics of poverty and poverty-related needs at the level of communities. These social enterprise organizations (SEO) have been identified as an alternative and/or a complement to the action of governments and international organizations to address unmet social needs (Seelos and Mair, 2005; Fowler, 2000; Defourny, 2001).

In-keeping with recent calls to account for institutional pressures stemming from the community in which actors are embedded (Marquis, Glynn, and Davis, 2007; Greenwood, Diaz, Li, and Lorente, 2007; Marquis and Lounsbury, 2007), we examine the relationship between poverty and SEOs as embedded in local communities. By local community we mean individuals 
living in a geographic territory and sharing some part of their identity, expectations and interests (Marquis and Battilana, 2009). In particular, we aim to understand how the concept of embeddedness enables a better understanding of the mechanisms that constitute poverty as a problem space and how this relates to the emergence as well as the particular strategies of SEOs. Jack and Anderson (2002) view embeddedness as a process of becoming part of local social structures and considered it a necessary mechanism for entrepreneurs to understand local rules, access local resources and to create value. Employing this analytic lens should also promote a more sophisticated conceptualization of poverty as an opportunity space for SEOs; one that goes beyond the traditional focus on social needs as natural opportunities.

We believe that a focus on communities provides a number of advantages for scholarly inquiry into the phenomenon of SEOs, and in this paper we are making the first steps in that direction. First, local communities constitute the principle realm in which SEOs act to explore and develop their business models. The focus on communities thus provides rich data adequate for exploratory research designs with the objective of theory building. Second, we argue that the institutional structures usually attributed as defining characteristics of communities with sustained poverty, create a social setting that constrains the set of choices for community actors. These communities thus resemble quasi-experimental situations in which event regularities can be observed (Lawson, 2003). This setting allows deeper reflections on and isolation of the social mechanisms that contingently generate the empirically observable phenomena of poverty and the mechanisms that SEOs generate to address it (Pawson and Tilley, 1997, Seelos and Mair, 2010). Furthermore, community-level inquiry facilitates comparative idiographic research designs that enable sensitive generalizations of findings (Tsoukas, 1989). Third, understanding how mechanisms relate to poverty as an outcome in social systems also requires analytical integration of factors external to the focal system. This is more challenging, for example, in country-level studies of poverty-related phenomena due to the contextual variation created by multiple neighbors with different cultural, political, and economic characteristics. Community-level approaches have the advantage of providing relatively homogenous environments that facilitate isolation of external mechanisms and their effects on the community.

The paper proceeds as follows: we first reflect on the opportunity space of social entrepreneurship at the community level. We then build on Scott's (2001) theorization of institutional pillars to characterize and understand community poverty. Using a number of illustrative cases we examine the relationships between institutional characteristics of communities and SEO embeddedness and emergence. Next, we contrast three strategic orientations that SEOs might choose in order to study how these strategies are influenced by and influence community characteristics. Finally, we discuss our emerging model of the dynamic relationship between communities and the emergence and strategic orientation of SEOs. We highlight implications for future research on the interaction between actors and their institutional context as well as for future research on social entrepreneurship. 


\section{Communities as Opportunity Spaces for Social Entrepreneurship}

\section{The Phenomenon of Social Entrepreneurship}

Definitions of social entrepreneurship vary greatly across the literature (for recent reviews see Short, Moss, and Lumpkin, 2009; Zahra, Gedajlovic, Neubaum, and Shulman, 2009). Many studies focus on the legal setup of not-for-profit structures combined with a central concern of many social enterprises to generate revenue and decrease reliance on outside donors (Dorado, 2006; Fowler, 2000; Jansson, 2001). Others focus on the primacy of the social mission within social enterprises over other organizational objectives. It has been argued that, no matter whether they adopt a for-profit or a not-for-profit legal form, SEOs are unique in that they involve a "hierarchical ordering of social and economic value" whereby social value takes precedence over the generation of economic rents (Dacin, Dacin, and Matear, 2007). In this paper we define social entrepreneurship as entrepreneurial activities with the aim of building organizations that achieve social goals (Mair and Martí, 2006). Irrespective of whether they adopt a for-profit or a not-for-profit legal form, such organizations, referred to hereafter as social entrepreneurial organizations (SEOs), are new ventures that are characterized by targeting poverty and poverty-related social needs as their prime objectives.

SEOs are not a new phenomenon. An increasing number of newly created organizations identify themselves as SEOs (Global Entrepreneurship Monitor, 2010). But we know very little about the conditions of their emergence and development. In an effort to address this issue, recent research on SEOs emphasizes the global nature of social entrepreneurship (Zahra, Rawhouser, Bhawe, Neubaum, and Hayton, 2008). While we acknowledge the importance of global forces in the emergence and the development of SEOs, we argue that, because SEOs are embedded (Dacin, Ventresca, and Beal, 1999) in a set of both global and local forces, the influence of local forces should not be overlooked. This neglect of local influence is surprising, given that SEOs most often aim to address locally situated social needs. Contrary to other initiatives that have transposed western models to local communities, SEOs tend to be embedded within local communities in the sense that they target the needs of a locally defined set of individuals.

Whereas earlier work on entrepreneurship (Johannisson and Nilsson, 1989; Jack and Anderson, 2002; Baker, Gedajlovic, and Lubatkin, 2005) accounts for differences in entrepreneurial initiatives across local institutional settings, research on social entrepreneurship has yet to pay systematic attention to differences in SEOs across institutional contexts, and, in particular, across a range of geographic communities. Given that only a few studies have started addressing differences in social entrepreneurship across countries (e.g., Kerlin, 2006), we set out to further explore how differences in local contexts might influence the emergence and development of SEOs.

\section{Community Needs as Opportunities for Social Enterprise Organizations}

One of the key features of entrepreneurship lies in the discovery, definition and exploitation of opportunities (Zahra et al., 2008). The existence of poverty-related social needs indicates an important opportunity space. Both relative and absolute poverty levels persist. At current speeds of income growth, there will still be 800 million people living below incomes of 1 USD per day by 2015 (Chen and Ravallion, 2007). Research has thus conceptualized the opportunity 
space for SEOs as a broad arena of unmet social needs (Austin, Stevenson, and Wei-Skillern, 2006) that relate to the economic, social, health and/or environmental aspects of human welfare (Zahra et al., 2008). However, if the extent of obvious poverty-related social needs seemingly defines a natural opportunity space for SEOs, then we need to address the question of why these obvious opportunities are not systematically picked up by entrepreneurs. We argue that this needs-based perspective on SEO opportunities requires conceptual expansion and refinement.

Moran and Ghoshal (1999) developed Penrose's (1959) concept of productive opportunities into a more general framework applicable to any system ranging from individual entrepreneurs to society as a whole. They conceptualized a productive opportunity as the local coincidence of a triad of factors: i) someone needs to perceive that the realization of the opportunity creates a valuable service; ii) the realization of the opportunity needs to be enabled by available resources, and iii) someone needs to be motivated to enact the opportunity. From this perspective, the existence of obvious social needs as argued above constitutes only one part of the productive opportunity space. It is the dimension of an opportunity that requires the SEO founder(s) to perceive a potential service catering to poverty-related social needs.

A second challenge for SEOs in realizing a productive opportunity lies in accessing the social and economic resources required to build a robust and locally effective organization. The context of community-level poverty often provides very limited resources for building efficient organizations (Seelos and Mair, 2007). Often, SEOs engage in a process of local experimentation and sense-making based on material and ideational bricolage, recombining readily available resources (Baker and Nelson, 2005; Mair and Martí, 2009). The third element of the opportunity space is partly determined by the very nature of poverty-related needs that SEOs tend to address and partly by the context in which they act. We are not aware of SEOs that have created significant material wealth for their founders comparable to the wealth created by strictly commercial ventures. Therefore, we postulate that the enormous benefit that an SEO can potentially realize for poor, underserved communities is expected to provide a strong motivating force.

The challenges of institutional rigidities and the potential failure to become embedded in the local context could threaten robust levels of access to local resources and sustained SEO staff motivation. We thus postulate that the emergence of SEOs is a consequence of the ability to orchestrate the multiple coincidence of the three dimensions of a productive opportunity space. Realization of this coincidence enables the emergence of a locally-embedded SEO as a prerequisite for any longer-term strategic approach an SEO might choose to enact.

\section{Embeddedness, Social Entrepreneurship and Community}

As emphasized in Tönnies's (1887) seminal distinction between Gemeinschaft and Gesellschaft (community and society), communities are different from larger and more impersonal forms of relationship such as society. Members of a community not only live in the same geographic territory, but are also characterized by a relative boundedness (Calhoun, 2001). As a result of living together in the same geographic territory, they share some parts of their identity, expectations and interests (Marquis and Battilana, 2009), which may under certain circumstances facilitate the creation of symbiotic relationships between SEOs and the local community in which they are embedded. 
Embedding is an important aspect of entrepreneurial activities. Prior work has demonstrated strong linkages between entrepreneurial action, which is locally embedded, and the institutional infrastructure of a region (George and Prabhu, 2000; Stark, 1996). As Jack and Anderson (2002) suggest, embeddedness allows entrepreneurs to become part of the local structure and therefore have the potential to access as well as constitute both latent and readily accessible resources and opportunities. Jack and Anderson (2002) provide two important insights. First, they highlight the strategic importance of embedding as a means of "anchoring" the entrepreneur in the local context. This allows them access to specialized knowledge regarding "local rules" of the game, credibility and resources necessary to carry out their entrepreneurial work. Second, Jack and Anderson (2002) acknowledge the diversity of means (both social and structural) with which entrepreneurs come to be embedded. Their findings shed light on the process utilized by locals, as well as non-locals, to embed themselves in their local communities. In doing so, their embeddedness both enacts and maintains the local context (Jack and Anderson, 2002).

This conceptualization of embeddedness views the local structure primarily as enabling entrepreneurial action. We expect that the relationship between institutional structures and mechanisms in poor communities and the SEOs that establish themselves there is likely to be different. Members of poor communities do not primarily organize their economic lives around markets and impersonal transactions but rather are deeply embedded in local community structures. Uzzi (1997) has highlighted the "dark side" of overembeddedness, i.e., when firms in a network are connected primarily through specific embedded ties as opposed to impersonal arm's length ties. Applying this concept at the level of community actors implies that overembeddedness tends to stifle institutional change by strongly discouraging deviant behavior. Overembeddedness is also expected to stifle economic action (Uzzi, 1997). This perspective would explain how the phenomena of poverty and poverty-related social needs are sustained by the particular local configuration of institutions in poor communities and the strong embeddedness of actors in these communities.

The characteristics of local embeddedness are also likely to influence whether and how productive social entrepreneurial opportunities are enacted. We argue that embedding of earlystage SEOs in the local context is an expected requirement for an organization to emerge. But we propose that the lack of enabling qualities that Jack and Anderson (2002) postulated for wealthier communities might require that SEOs also change rather than merely constitute or reenact local structures during the embedding stage or at later stages of operating a more mature SEO. This process of partial disembedding would constitute a mechanism that could open new trajectories of escaping poverty for community members.

Institutional mechanisms stemming from the community level, including regulative, normative and cognitive forces (Scott, 2001) are expected to influence the emergence of SEOs. Regulative forces yield coercive pressures to exert control over actors in the community. Normative mechanisms arising from the social structure shape the standard of appropriate and expected behaviors within the community. Finally, the structures of cognitive distinctions and taken-forgranted understandings result in shared path-dependent categorizations of individual and collective actors and templates of associated ways of acting within the community. These institutional mechanisms shape the context of social entrepreneurial organizations by serving to create meaning systems and norms of conduct. They also contribute to shaping actors' perceptions and enactment of the productive opportunity space as conceptualized above. Therefore, we expect institutional mechanisms to influence SEO action by supporting an 
understanding of local rules and the identification of services that fit local poverty-related social needs, by providing access to local resources, and by affecting the level of motivation for entrepreneurs to enact the opportunity. In short, because they shape the local productive opportunity space, institutional forces influence the emergence of SEOs.

\section{Regulative Influences on the Emergence of SEOs}

The regulative structure of communities corresponds to the formal rules and incentives established by local public authorities and other empowered agents of the collective good to constrain and regularize behavior. In Scott's formulation (2001, p. 52), “...regulative processes involve the capacity to establish rules, inspect or review others' conformity to them, and, as necessary, manipulate sanctions - rewards or punishments - in an attempt to influence future behavior."

A defining feature of entrepreneurship is the necessity for entrepreneurs to make decisions under conditions of uncertainty. Uncertainty implies that the entrepreneur knows neither the range of possible outcomes of her decision nor the likelihood of these outcomes (Knight, 1921). Uncertainty related to the regulatory context may be an important hurdle towards the building of SEOs. Seelos and Mair (2007) highlight the many regulative issues and hurdles that delayed and hindered the establishment of SEKEM, an SEO that aims to contribute to the development of Egypt in the economic, cultural and social spheres. Over a period of more than 30 years SEKEM has transformed a piece of desert land North of Cairo into an organization comprising several businesses that are active in organic agriculture along with a medical center and educational organizations among others. In the case of SEKEM, uncertainties related to the regulatory context influenced the level of motivation of the entrepreneur to continue to act on the opportunity. In its early years, SEKEM ran into disputes with the local Bedouin over land use rights. The Bedouin, who were nomadic and lived outside the regulatory norms of the country, challenged SEKEM's legal ownership rights to the land it had acquired. Settling this dispute, according to the autobiography of the main entrepreneur behind SEKEM, was close to a life-or-death endeavor that severely challenged his level of motivation to proceed (Abouleish, 2004). A few years later, the military occupied the land upon which SEKEM had built its first farms and almost eliminated any hope for progress. Corrupt public authorities also stopped initial attempts to cultivate the land using biodynamic methods, arguing, despite the fact that biodynamic agriculture was already well established in other parts of the world, that this would contaminate the soil with dangerous bacteria. All these events highlight mechanisms by which the inability to remove regulatory uncertainty may prevent an SEO from becoming productively embedded in local structures. This poses a serious challenge to building a robust organization. Today, SEKEM is deeply embedded in Egyptian communities as well as the regulatory structures of Egypt, with deep relationships at the political level as well. As an SEO they are growing and expanding their scope well beyond the original communities that shaped their early business model.

Foreign Policy, together with the Fund for Peace, releases yearly reports on "failed states," which are defined as those "in which the government does not have effective control of its territory, is not perceived as legitimate by a significant portion of its population, does not provide domestic security or basic public services to its citizens, and lacks a monopoly on the use of force." The "failed" status of states, indicative of the relationship between the state and society (Evans, 1995), is likely to get transferred to the community level (Woolcock, 1998).

\footnotetext{
${ }^{1}$ The Failed States Index (2007) Foreign Policy; July/Aug. 2007, Issue 161, p. 54-63.
} 
When communities are characterized by "failing" local public authorities, they are vulnerable to violent internal conflict over power and identity by competing ideologies or ethnic groups. For example, the hostile environment to set up an SEO targeting communities in Afghanistan has been described by BRAC, one of the largest NGOs in Bangladesh and an oft-cited example of a successful SEO. BRAC found it difficult to replicate the organizational model they developed in Bangladesh within communities in Afghanistan. In a Bangladeshi newspaper article dated September 17, 2007, the executive director of BRAC, Dr. Mahbub Hossain, told reporters after a meeting with the acting foreign secretary: "We are concerned about the incidents of killing and abduction in a week. If the killing and abduction of our staff [... is] politically motivated, we have to rethink the operation."

SEOs will find it difficult to operate in communities where the security of their staff is endangered, when claims over resources are constantly challenged and when assets are continuously destroyed, thus seriously undermining the motivation levels of SEO staff. In such communities, where public authorities have limited power and conflicts over legitimacy are frequent, the ability and motivation to enact opportunities are severely challenged and we expect to find fewer numbers of SEOs than in more politically stable communities. From this perspective, SEOs do not seem to have different powers and abilities than most other organizations. Even large established multinationals with deep resource endowments and political clout struggle in such environments. The annual report of the Shell corporation documenting its operations in Nigeria is a peculiar and enlightening illustration of this claim. ${ }^{2}$

\section{Normative Influences on the Emergence of SEOs}

The normative structure of communities is composed of a socially designed set of prescriptions that shape the boundaries of appropriate action. Scott's (2001, p. 54-55) definition focuses on the "prescriptive, evaluative and obligatory dimension (of) social life" as the basis for creating a stable social order. We argue that local norms shape the standards of appropriateness within communities, thereby influencing SEOs' emergence and their strategic orientation. DiMaggio and Powell (1983) highlight the importance of social connections in diffusing standards of appropriateness. We argue that local relational systems shape the standards of appropriateness within communities, thereby influencing SEOs' emergence and development.

Numerous studies have highlighted the importance of social capital in social entrepreneurship (Mair and Martí, 2006). Social capital can broadly be conceptualized as the collection of resources provided by a person's network of friends, family, associates, community organizations, and the accepted norms and practices that govern their interactions (Burt, 2001; Woolcock and Narayan, 2000). Social entrepreneurs need social capital both to mobilize resources in the community in which they are embedded and to achieve their social mission as well as any financial objectives they might have. Although there is agreement on the importance of social capital, disagreement remains over the community network structures that create and sustain it.

On the one hand, networks with a relatively high degree of closure produce enforceable trust, which is likely to facilitate the action of social enterprises within a given community. Enforceable trust refers to the network's ability to force network members to comply with accepted norms. Group members will honor commitments and will not act opportunistically

\footnotetext{
${ }^{2}$ Available at http://sustainabilityreport.shell.com/2008/buildingaresponsibleenergyfuture/nigeria.html
} 
because of the threat of sanctioning by the network. If a network lacks closure, it will be unable to collectively act to punish offending individuals (Portes and Sensenbrenner, 1993; Coleman, 1988). The Grameen Bank drew on enforceable trust to lower the transaction costs associated with enforcing repayment of its microfinance loans. The bank only gave loans to women, believing that men were too mobile with too many connections outside of their community. Additionally, loans were only given to groups of women with the belief that the group had the power to enforce each individual to repay the loan. These Bangladeshi women were deeply rooted in their communities with few links to other networks. Hence, enforceable trust stemming from network closure is a valuable resource that social enterprises can utilize to lower transaction costs as a prerequisite of financial sustainability.

On the other hand, a high degree of closure within a community can also prevent the emergence of SEOs. Uzzi (1996) has drawn attention to the potential liability of high levels of structural embeddedness. His analysis implies that, beyond a certain threshold, the costs of embeddedness exceed the benefits it creates. Without ties to outside groups, the community may not be able to access new ideas and could become locked into certain inefficient practices, thereby preventing any change, including the emergence of SEOs. Indeed, a network that bridges structural holes can also be a form of social capital (Burt, 2001). A person who bridges structural holes can access information held in multiple networks. Perhaps more importantly, she can also control the flow of information between networks. Social entrepreneurs are often boundary spanning actors, linking the community they are trying to help to outside networks. These linkages provide the social enterprise with new sources of information and capital (Alvord, Brown, and Letts, 2004).

Bridging both lines of argument, we maintain that a moderate degree of closure will lower transaction costs and increase the sense of collective identity within the community, increasing the likelihood of emergence of SEOs. A community that is entirely closed from outside networks, however, might prevent the emergence of social entrepreneurship initiatives. Therefore, we suggest that there is an inverted U-shaped relationship between the degree of closure of communities and the likelihood that SEOs will emerge in these communities.

Recent studies detail how BRAC's engagement with poor women in local communities in rural Bangladesh helped to overcome traditional stifling norms that prevented women's participation in economic life (Seelos and Mair, 2009; Martí and Mair, 2009; Mair and Martí, 2009). Changing norms takes time and builds on tacit hands-on engagement. This poses challenges for SEOs in securing resource availability and sustaining levels of motivation. We propose that the emergence of SEOs will be negatively correlated with community cultural propensities that hinder the ability of people to engage in economic activities.

The capacity for hands-on engagement to change collective norms may be constrained by community size. In their study of community based enterprises (CBE), Peredo and Chrisman (2006) argue that CBEs are less likely to emerge in large communities. Large communities with complex and fragmented networks are less likely to achieve solidarity and be motivated towards collective action. We argue that this relation is positively mediated by community norms that stifle economic engagement by all or significant parts of the community. This coincidence of institutional and demographic factors is expected to pose severe challenges to SEOs becoming embedded in local communities and building robust organizations. 


\section{Cognitive Influences on the Emergence of SEOs}

Cognitive structures provide readily available scripts for actors (Barley and Tolbert, 1997; Dacin, Ventresca, and Beal, 1999; Scott, 2001). Taken together they constitute shared templates that facilitate the adoption of similar practices for members of a community. These shared templates are tied to longstanding identity and tradition associated with local communities. Cognitive structures thus shape and articulate conceptions of value and social needs, and therefore acceptable solutions. We rely on a view of cognitive embeddedness that gives prominence to the role of broader social cognitions in shaping action (Walsh, 1995) as well as the existence and strategic importance of collective or shared cognitive models. A focus on cognitive embeddedness draws attention to the need to understand how localized structures diffuse and come to be taken for granted as appropriate and habitual (internalized) pathways for fulfilling social needs within a given community. According to Reger and Huff (1993), the emergence and existence of localized cognitive structures serve to simplify an otherwise complex set of problems and solutions. As such, cognitive structures provide actors with systems of shared understandings, meanings, and expectations to guide action. We argue that cognitive processes stemming from the community level will influence the emergence of SEOs by imposing abstract rules associated with the structure of cognitive distinctions and taken-forgranted understandings.

Addressing the question of why industrial districts developed in certain regions but not in others, scholars found that cultural characteristics of certain regions enabled the development of industrial districts (Sabel, 1989). The sustainability of cultural traditions or systems of shared meaning (values and beliefs) within a given region serves to impact the emergence of new organizations in several ways. First, shared values bind local actors to each other and across time in a vast and complex array of social networks. This system of social ties enables local communities to craft cohesive identities (Jack and Anderson, 2002).

Second, cultural traditions of a given region enable communities to claim their local distinctiveness (Marquis and Battilana, 2009; Mizzau and Montanari, 2008). Mizzau and Montanari's (2008) work on the distinctiveness of Piedmont's music district demonstrates that creativity of a region is, to a large extent, embedded in localized geographic and cultural contexts. The cultural sustainability of traditions in a given region leads to the emergence of localized and distinctive clusters (Scott and Storper, 2003). Local culture serves to reify boundaries of acceptable action within a given region thereby limiting what newcomers to a particular community can do, at least initially. Local heritage and traditions serve as important signals and sanctions for prospective newcomers. Economists have highlighted the fact that social and economic development is often stifled by the dominance of local "rules of the game" (North, 1990).

For example, in Italy, the tradition of entrepreneurship that characterized certain areas facilitated the development of industrial districts (Bagnasco, 1995; Trigilia, 1995). Such a tradition of entrepreneurial activity enables communities to accumulate knowledge and skills about how they should shape entrepreneurial ventures, including social enterprise initiatives. Perrini, Vurro and Costanzo (2008), who examine the case of San Patrignano, an organization that uses an "earned income" strategy to support its drug rehabilitation community in Italy, explain how the local tradition of entrepreneurial activity facilitated the emergence and the development of this unique organization, which manages 56 businesses in total, including wine-making, cheese-making, horse- and dog-breeding, furniture design and artwork. 
In Kenya, thousands of small farming communities remain poor because they rely on the irregularities and unpredictability of nature to provide the water required to grow produce that can be sold in small local markets. Although they are culturally adapted to a cash-based economy and to moderate levels of subsistence entrepreneurship, they have been unable to cognitively perceive opportunities to develop their micro-enterprises. Two social entrepreneurs introduced simple locally manufactured irrigation pumps that they called "Super Money Makers." The introduction of a new category of objects in the form of a supporting technology established new shared templates for more productive farming that was readily adopted by local communities. The emerging SEO was called ApproTec - short for "Appropriate Technology" and later renamed Kickstart. It introduced a number of very simple local technologies and tools that communities could not conceive of but that fit the local culture of engagement in small enterprises.

The existence of a local entrepreneurial tradition provides much-needed legitimacy for entrepreneurial activities and enables rapid adoption and diffusion of new economic templates for productive engagement. Therefore, we suggest that SEOs are more likely to emerge in communities where there is a tradition of entrepreneurial activity than in other communities.

\section{Embedding, Disembedding and SEO Emergence}

The case studies mentioned above illustrate the variation of local institutional mechanisms across communities. They also show how this institutional variation, in turn, shapes variation in the local face of poverty and poverty-related needs, and how it relates to the ability of SEOs to emerge as observable organizational entities. As the case of SEKEM illustrates, embedding in the local regulatory structures by forming predictable relationships with powerful actors was a prerequisite for building an SEO. It enabled securing access to resources and avoided frustrating "surprises" of arbitrary interferences by powerful actors that could damage the morale and levels of motivation of the SEKEM entrepreneurs. The ability of the Grameen Bank to leverage the closure provided by strongly embedded ties amongst women was a crucial resource and thus a prerequisite to establishing a line of microfinance services. Following the line of argument established earlier, embedding was necessary to orchestrate the multiple coincidence of a productive opportunity and the emergence of an SEO. Conversely, because BRAC was not able to become embedded in Afghanistan, it is still exploring how to enact the productive opportunity space for Afghan communities and remains in a vulnerable state of emergence.

On the other hand, BRAC's focus in Bangladesh on the exclusion of poor women from economic activities first required the changing of certain norms to enable the provision of services to a community that engaged women as active participants. Thus, BRAC needed to balance both embeddedness (to access and build local resources, e.g., trust) and disembeddedness (changing institutional structures to enable female participation as part of the service proposition) in order to realize its productive opportunity.

We propose that emergence of SEOs is constituted by the realization of a productive opportunity space and that both embedding and disembedding are contingent processes required for realizing this opportunity. Unlike the entrepreneurs described by Jack and Anderson (2002) SEOs both enact and modify local structures. As argued previously, we propose that modifying local institutions, i.e., disembedding, is required for the sustained ability of an SEO to change the local dynamics of poverty. This requires strategic choices about 
services, resource requirements and allocations, as well as strategies for sustaining levels of motivation beyond the explorative enactment of a productive opportunity space.

\section{Strategic Orientations for Addressing Poverty and Poverty-Related Needs at the Community Level}

Existing discussions have predominantly focused on whether SEOs adopt a for-profit (FP) or not-for-profit (NFP) organizational form (Hockerts, 2006; Bradach, 2003; Tracey and Jarvis, 2007). This distinction does not adequately capture the richness and complexity of the phenomenon. We depart from this FP and NFP categorization and examine three strategic orientations that SEOs might adopt to locally address poverty-related social needs; namely a collective action orientation, a market-based orientation and a social giving orientation. Strategic orientations are cognitive models or frameworks utilized to process information and shape organizational decisions (Hitt, Dacin, Tyler, and Park, 1997). In our view, these three strategic orientations represent ideal types (Weber, 1904) and we suggest that an SEO could adopt one or more approaches at any given time or change their approaches dynamically over time as new challenges and opportunities arise.

We view strategic orientations as dependent on the particular characteristics of prior enactment of a productive opportunity. Thus, institutional mechanisms are expected to influence strategic orientations. Because of the need to change local institutions to enable progress as argued above, we also postulate that institutional mechanisms may be a target of SEO strategic action in an iterative dynamic.

\section{Collective Action Orientation}

SEOs that adopt a collective action orientation co-opt the local community as an active collaborator in the entrepreneurial effort. Community-based entrepreneurship is an example of SEOs empowering a local community to act entrepreneurially and facilitate development (Johannisson and Nilsson, 1989; Peredo and Chrisman, 2006). Collective action orientations are widespread among SEOs interested in building local arenas for development (Johannisson and Nilsson, 1989).

For example, SEOs promoting self help groups (SHGs) often adopt a collective action orientation. The Self-Employed Women's Association (SEWA), founded in Ahmedabad (India) in 1972, is an example of an SEO adopting a collective action orientation to organize its members (Alvord, Brown, and Letts, 2004). SEWA members are female workers who have no fixed employee-employer relationship with welfare benefits; they depend on their own labor for survival and barely have any assets or working capital. SEWA's main goal is to give these women access to work security, income security, food security and social security (including health care, child care and shelter). To do so, SEWA has helped women take the initiative in organizing their own support services such as savings and credit, health care, child care, insurance, legal aid, capacity building and communication services. These services are provided in an affordable manner at the doorsteps of workers, and women are happy to pay for them. This results in the financial viability of support services, which can be and indeed are themselves a source of self-employment. At a community level, SEOs like SEWA thus provide a platform for marginalized groups to actively address social issues which are often taboo, such as abuse of women, dowry, education, and others depending on local realities, and thereby 
begin to build the necessary infrastructures for their economic development (Martí and Mair, 2009).

We suggest that a community's level of closure is likely to influence an SEO's strategic orientation. Networks with a relatively high degree of closure produce bounded solidarity, which refers to situational circumstances galvanizing a community towards collective action. For example, Chinese immigrants in the United States, upon meeting with intense discrimination, "had no recourse but to band together in tightly knit communities that were the precursors of today's Chinatowns" (Portes and Sensenbrenner, 1993). These tightly knit communities served as a foundation for the rapid growth of Chinese enterprises in the United States (Portes and Sensenbrenner, 1993). The presence of such bounded solidarity in a community is likely to influence SEOs to adopt a collective action approach. We propose that the higher the degree of closure of communities, the more likely SEOs are to adopt a collective action orientation.

SEKEM in Egypt also uses a group mechanism to overcome cognitive hurdles of employees who do not understand the importance of showing up at work in a predictable manner and on time; something which is clearly required for building a robust and sustainable SEO. SEKEM employs a collective action mechanism to achieve this goal: every organization of the SEKEM group forms a morning circle consisting of all employees. Not being there on time is highly visible and thus embarrassing for individuals. This mechanism creates new templates for role-behavior required for efficient economic activities. It builds capacity for SEKEM to instill new rules and monitor behavior, thus creating new regulative structures within the community.

In communities characterized by "failing" public authorities, power inequalities are very likely to be exacerbated. In an effort to fight these inequalities, SEOs will need to draw on the power of others in the community by co-opting and capturing their interest. Collective action provides a valuable source of much-needed power to execute the entrepreneurial effort in such situations (Martorana, Galinsky, and Rao, 2005). We thus propose that SEOs are more likely to adopt a collective action orientation as a means of equalizing or regaining control over power differentials. For example, Gram Vikas, an NGO in India, uses this mechanism to engage people from lower castes who otherwise would be locked in isolated social positions from which personal growth is impossible. Gram Vikas tackles caste-based and gender inequalities by mobilizing communities around a common goal: the provision of a constant supply of safe drinking water and vast improvements in the health and sanitation of a village. Resistance to the inclusion of the lower caste members of the village is initially very strong and these families are themselves reluctant to participate, owing to what Gram Vikas refers to as an 'acceptance of their fate to be excluded.' Women are also habitually excluded from any decision-making or economic activities, but Gram Vikas insists on 100 per cent participation by both women and men of all castes in the village water and sanitation project and uses the goal of creating a much-needed community water supply, to mobilize and unify these oppositional constituencies (Mair, Martí, and Ganly, 2007).

\section{Market-Based Orientation}

SEOs that adopt a market-based orientation rely on exchange mechanisms and harness market forces to pursue their objective. They identify and exploit market opportunities by offering products and/or services whereby local realities considerably shape the design of the specific business model. Muhammed Yunus' (2007) concept of the 'Social Business Entrepreneur' 
provides an interesting example of this orientation. Yunus' Grameen Bank and Norway's main telecommunications company, Telenor, co-founded an SEO that provides the rural poor in Bangladesh with access to modern communication technology (Seelos and Mair, 2007). The joint effort has created tremendous growth in rural employment and economic activity. Grameen Bank provides micro-loans to women to purchase mobile phones as the basis for micro-businesses. This provides communities with access to market information, e.g., about prices for agricultural products or information that enables better harvesting and planting decisions. This also has a transformative effect on communities by engendering new habits such as regular conversations with relatives abroad. Another consequence is a cognitive shift brought about by changing the traditional roles of women in rural villages. Women with a mobile phone business are able to change their role from an economically and politically marginal community member to one of the most central and powerful members based on ownership of a crucial community resource - access to information and social communication. As this example shows, when SEOs adopt a market-based orientation, they aim to make social and economic value creation occur in parallel.

Market-based solutions can be the consequence of cognitive shifts that reconfigure unproductive economic factors into new business models. Before Yunus established the Grameen bank, he tried to convince regular banks to provide the poor with small loans. However, the prevailing cognitive perspective that "one cannot do business with the poor" kept the rural poor caught in poverty traps resulting from exploitation by middlemen who provided loans at such extremely high interest rates that rural workers were denied the possibility of savings and investments and thus economic growth.

In Kenya, for a long time, farmer communities had failed to identify better water management as an opportunity to escape poverty. Two entrepreneurs founded the SEO Kickstart reflecting a developing focus on helping micro-businesses to take off. This focus led to the creation of a whole value chain for the local production, distribution, promotion and sales of cheap water pumps that provided farmers with a resource for dramatically improving yields and thus income levels.

\section{Social Giving Orientation}

SEOs that adopt a social giving orientation rely on external financial (i.e., donations) and human resources to support their activities. For example, Comitê para Democratização da Informática (CDI) in Brazil uses local resources from the community in terms of facilities, fees paid by students, and volunteer work as well as donations from companies and foundations to promote the social inclusion of disadvantaged people through the use of information and communication technologies (Mair and Seelos, 2006). Similarly, Unis-Cité, which is the first organization that developed a youth civilian service in France, is another example of an SEO opting for a social giving orientation (Anteby, Battilana, and Pache, 2007). It relies on a mix of public and private funding to finance its activities. Unis-Cité programs, which now exist in ten different cities, offer young people aged 18 to 25 from all ethnic and social backgrounds the opportunity to participate in full-time team-based community service projects during a period of approximately nine months. The teams of young people managed by Unis-Cité staff are assigned to various projects, all aiming to help the local community to which they belong.

Cultural-cognitive forces stemming from the community are likely to influence SEO's strategic orientation. We propose that, in communities with a tradition of philanthropic activity, SEOs 
are more likely to adopt a social giving orientation. SE0s arising in these communities would adopt orientations in line with others in the community so as to facilitate the flow of legitimacy and ultimately, resources. Galaskiewicz's studies of philanthropy in the twin cities region of Minnesota sheds light on the patterns of corporate giving that arise, in large part, as a result of robust networks and personal ties to local philanthropic leaders. However, Galaskiewicz's argument is more nuanced than simply a story about networks- the networks that promoted a tradition of giving in the twin cities are robust because of the presence of durable social structures or longstanding local norms and institutions that support their formation and maintenance. Galaskiewicz $(1991,1997)$ describes how new corporate leaders underwent a process of socialization in line with the local culture, norms and traditions. Through this process the tradition of corporate giving was maintained over time and became an institutionalized practice in its own right. We argue that, in communities characterized by such a tradition of private or public donations, SEOs are more likely to adopt a social giving orientation.

A social giving orientation is also employed to target deeper levels of poverty or to engage in capacity building work. BRAC in Bangladesh operates special programs to enable the "ultra poor" to build the capacity to engage in economic activities. This requires investments into creating human and social capital over long periods of time. BRAC also runs basic schools for poor children and healthcare services. Many of these do not lend themselves to market-based activities and collective action strategies.

\section{Table 1}

Summary of the Main Characteristics of SEO Strategic Orientations

\begin{tabular}{|c|c|c|c|}
\hline & \multicolumn{3}{|c|}{ STRATEGIC ORIENTATIONS } \\
\hline & Collective action & Market-based & Social-giving \\
\hline Locus of SEO Activities & $\begin{array}{l}\text { Single community with high } \\
\text { degree of closure or separate } \\
\text { communities of comparable } \\
\text { institutional settings and } \\
\text { poverty characteristics } \\
\text { (facilitates experimentation } \\
\text { and replication) }\end{array}$ & $\begin{array}{l}\text { Exchange relationships } \\
\text { between communities, often } \\
\text { with different institutional } \\
\text { settings and poverty } \\
\text { characteristics (displaying } \\
\text { differential resource } \\
\text { endowments) }\end{array}$ & $\begin{array}{l}\text { Single communities with } \\
\text { high levels of inequality or } \\
\text { high levels of community } \\
\text { poverty in relation to its } \\
\text { context (high relative } \\
\text { poverty levels) }\end{array}$ \\
\hline $\begin{array}{l}\text { Main Objectives and } \\
\text { Mechanisms of Change }\end{array}$ & $\begin{array}{l}\text { - Aggregating weak } \\
\text { individuals to generate } \\
\text { collectives with the power } \\
\text { to overcome stifling } \\
\text { structures } \\
\text { - Generating social control } \\
\text { (instill rules) or social } \\
\text { compliance as } \\
\text { prerequisites for } \\
\text { productive economic } \\
\text { activities } \\
\text { Articulating common } \\
\text { community goals as } \\
\text { higher-level shared } \\
\text { objectives to overcome } \\
\text { structural mechanisms of } \\
\text { inequality, exclusion, and } \\
\text { power differentials } \\
\text { between community } \\
\text { members }\end{array}$ & $\begin{array}{l}\text { - Brokering between } \\
\text { different types of } \\
\text { resources to facilitate } \\
\text { exchange (institutional } \\
\text { mediation) } \\
\text { - Creating arbitrage } \\
\text { opportunities to enable } \\
\text { productive market-based } \\
\text { transactions } \\
\text { - Using economic activities } \\
\text { to change social } \\
\text { structures and co-create } \\
\text { financial and social value } \\
\text { Connecting supply chains } \\
\text { to diversify risk across } \\
\text { vulnerable communities } \\
\text { or to link isolated } \\
\text { resources into a } \\
\text { productive value chain }\end{array}$ & $\begin{array}{l}\text { - Providing external } \\
\text { resources to overcome } \\
\text { community bottlenecks } \\
\text { for economic activities } \\
\text { - Accessing donated } \\
\text { resources to build } \\
\text { capacity and change } \\
\text { institutional structures at } \\
\text { deeper levels of poverty } \\
\text { with no possibility for } \\
\text { generating adequate } \\
\text { economic returns } \\
\text { Getting resources to } \\
\text { address urgent social } \\
\text { needs directly without } \\
\text { necessarily changing the } \\
\text { structural dynamics that } \\
\text { create the needs (e.g., } \\
\text { post-conflict or natural } \\
\text { disaster scenarios) }\end{array}$ \\
\hline
\end{tabular}




\section{Discussion and Implications}

In this paper, we develop several ideas that allow us to better understand the linkages between social entrepreneurship and its embeddedness in communities. In doing so, we highlight a number of mechanisms through which local institutional structures influence the emergence and development of SEOs.

In an effort to develop the traditional needs-based view of SEO opportunities into a more sophisticated model with higher explanatory potential, we engaged Moran and Ghoshal's (1999) concept of productive opportunity. Our case examples illustrate this productive opportunity space for SEOs as the required coincidence of several factors at the level of the local community. Thus, the particular social needs that reside within poor communities are perceived by an entrepreneur as that part of a productive opportunity for which SEO services are expected to create value. For the entrepreneur and the SEO she builds, becoming embedded is a prerequisite for accessing and building local resources, including the trust of community members, and also, as illustrated in the case of SEKEM, forming stable relations with powerful external stakeholders. Embedding also provides the SEO with an understanding of how the unique configuration of local institutional mechanisms generates empirically observable outcomes, i.e., the local and partly idiosyncratic "face of poverty." For certain needs and community contexts, a balance of embedding and disembedding may be required for an SEO to emerge. This could be the case if changing norms is an integral part of providing a service, as we have seen in the case of BRAC.

Our cases indicate that the spatio-temporal idiosyncrasy of institutional configurations at the levels of individual communities is an important driver of variation in SEO emergence and eventual strategic direction. We also propose that the ability to become embedded locally is an important factor in sustaining the motivation of the entrepreneur and the emerging SEO to keep exploring an effective business model and to build a robust organization. Accordingly, whether or not an SEO emerges is dependent on enacting this multiple coincidence of a productive opportunity space locally. The coincidence of three elements - a service proposition that delivers value for communities, the ability to access or develop resources, and the sustained motivation to act - thus constitute an analytically fruitful conceptualization of the productive opportunity space for SEOs. In this paper we have engaged institutional theory to highlight the structural mechanisms that both shape this opportunity space at the level of communities and determine the success of realizing a productive opportunity, as indicated on the left side of Figure 1.

The eventual strategic direction that an SEO employs is - in our model - a result of several factors. Our cases indicate that entrepreneurial choices about these factors underlie variation in the observable strategic directions of SEOs. Strategic choices depend on the levels of local resources that the SEO is able to access or build and on the particular social needs the SEO wants to address. Choices are also the result of interpretations of the relevant local institutional mechanisms affecting community poverty. For example, in poor Egyptian communities, some children are forced to work at young ages to provide much-needed family income. Child labor is often framed in a way that is normative to Western societies and thus considered morally unacceptable. The resulting strategic choice for an organization might be to refuse to tolerate any incidence of child labor. However, this does not solve the underlying problem of family dependence on income. SEKEM decided to frame the problem differently. Recognizing child labor from a cognitive perspective that institutionalizes the roles of certain children as crucial means of family survival, SEKEM shaped an innovative strategy based on a social-giving orientation. SEKEM employs children to work on light tasks in the morning which secures the 
income for their families. In the afternoon, SEKEM uses financial resources from its businesses as donations to provide free schooling to these children. This strategy creates a mechanism that generates different future life-choices and life-trajectories with greater potential once the children grow up. SEKEM remained embedded in the traditional social family structures of the communities they operate in to sustain trust and relevance as an SEO. At the same time, SEKEM's intervention achieves a partial disembeddedness of the children from the traditional social structures that otherwise limited their future choices. Figure 1 provides a model that summarizes our emerging perspective on the interaction between institutional forces and social needs at the community level and the relation between emergence as well as strategic orientation of SEOs.

\section{Figure 1. Model of Community Factors, SEO Emergence and SEO Strategic Orientation}

"V" indicates variation across communities: i) local institutional mechanisms and characteristics of community poverty and poverty-related needs; ii) SEO emergence through processes of embedding and disembedding, and iii) SEO strategic orientation

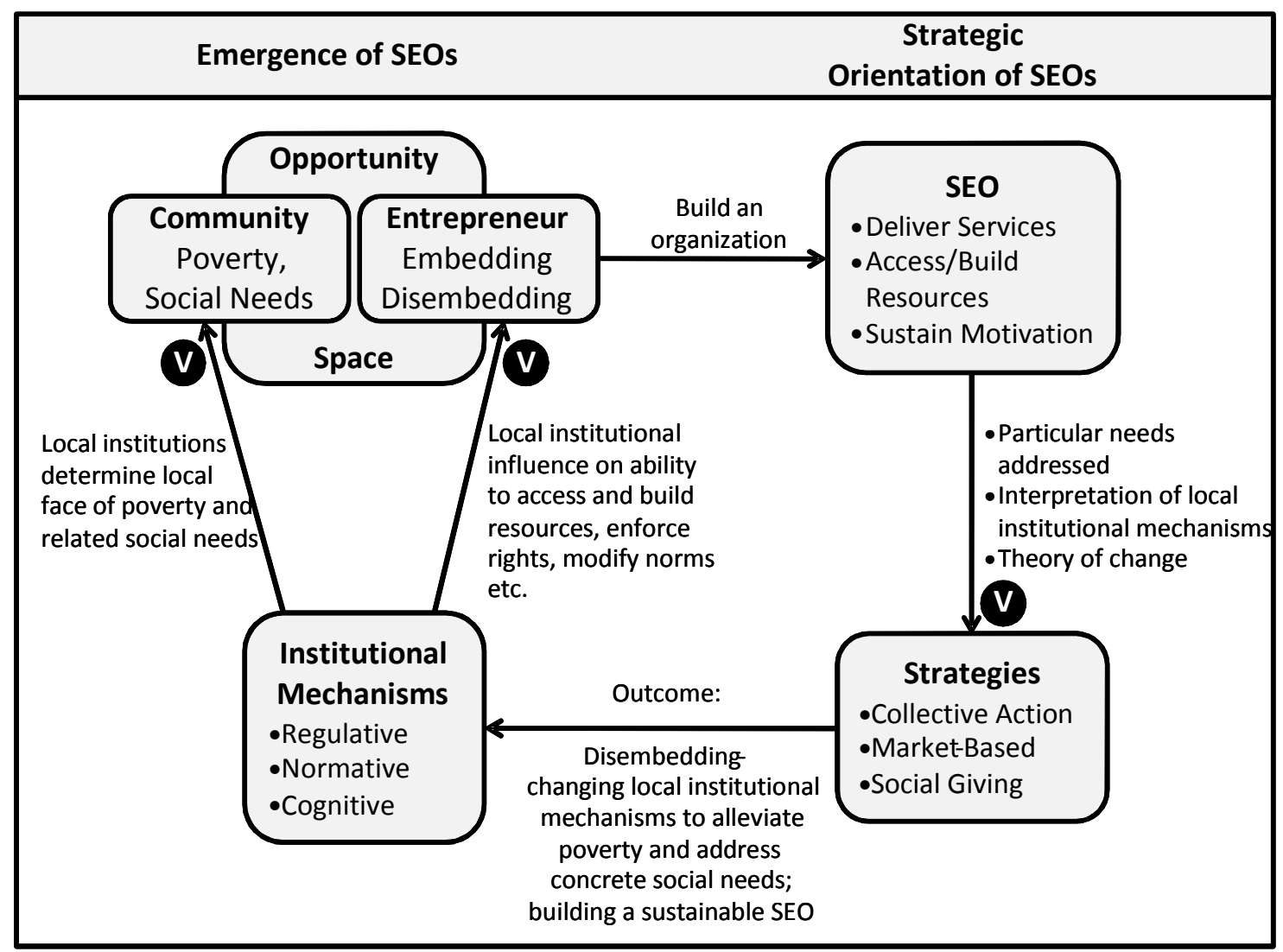

By highlighting the influence of institutional pressures stemming from local communities on SEOs, our work opens the way for new theoretical and empirical research about the interactions between communities and social entrepreneurs. This has the potential to contribute both to the social entrepreneurship and institutional theory literatures. Over the last decade, social entrepreneurship has enjoyed emerging interest from various disciplines and theories, yet as a scholarly field of investigation it is still in its nascent form, and definitions of social 
entrepreneurship vary widely. Judging from the diversity of meanings, definitions, and settings used to study it, social entrepreneurship represents an "umbrella construct," embracing a diverse set of phenomena (Hirsch and Levin, 1999). While some define social entrepreneurs as any actors who provide an innovative solution to an unmet social need, others focus on the need to create a new organization with a social mission for an actor to qualify as a social entrepreneur. Still others insist on the necessity for the newly created organization with a social mission to generate its own revenue to qualify as a social enterprise initiative. In this paper, we have focused on one form of social entrepreneurship, namely entrepreneurial activities with the aim of building new organizations that achieve social goals. We further distinguish three strategic orientations that SEOs might adopt. Our purpose is to develop a perspective on social entrepreneurship, which is researchable and explorative. Such a perspective is necessary to make empirical and theoretical advances.

Our paper contributes to the social entrepreneurship literature by providing a framework for understanding how differences in local institutional contexts might influence social entrepreneurship initiatives. It suggests that research on social entrepreneurship should systematically account for the community level of analysis. Doing so will help scholars to better address the central issue of scalability. Recent research on social entrepreneurship has focused on the challenges of scaling up, i.e., expanding the impact of SEOs (e.g., Bradach, 2003; Dees, Battle Anderson, and Wei Skillern, 2004; Pache and Chalencon, 2007; Seelos and Mair, 2010). Most of these challenges stem from the fact that the majority of social enterprise initiatives are locally embedded. This paper opens the way for research that will help better identify the initiatives that are more likely to scale up successfully.

Conceptualizing opportunities for social entrepreneurship has attracted an important debate among entrepreneurship scholars, and challenges existing views on one of the core concepts of entrepreneurship research. Traditional typologies of opportunities differentiate between entrepreneurial opportunities that are discovered and opportunities that are created (Alvarez and Barney, 2007), and are typically built on the assumption of the rent-seeking or profitmaximizing entrepreneur (Zahra et al., 2008). Theorizing efforts around social opportunities requires more inclusive assumptions about entrepreneurial motives and outcomes (Austin, Stevenson and Wei-Skillern, 2006). As a result, research on social entrepreneurship has the potential to expand and/or redefine the scope of entrepreneurship as a field of scholarly investigation.

Our model also contributes to the institutional theory literature by reviving the community level of analysis, which has been largely neglected in institutional theory over the last decades. While there is an emerging body of research about the interactions between actors and the community in which they are embedded (Marquis, 2003; Marquis, Glynn, and Davis, 2007; Greenwood, Diaz, Li, and Lorente, 2007), most recent institutional studies continue to focus on the field level of analysis while neglecting the local community level of analysis.

While we focused in this paper on the local context within which SEOs are embedded, we of course recognize that SEOs might also be embedded within other types of communities, which comprise actors sharing common identities but who may be geographically dispersed across local communities, as in communities of practice or virtual communities (Anderson, 1983). Many SEOs are part of transnational communities of practice and/or professional communities that transcend the boundaries of geographic communities. The social capital or networks formed by social entrepreneurs in such communities might serve to transport values, understandings and solutions across geographic communities. For example, the networks 
created by venture philanthropy organizations such as Ashoka, EchoingGreen and the Schwab Foundation, may contribute to the diffusion of new ideas and practices in the field of social enterprise, thereby influencing the likelihood of emergence of SEOs as well as their strategic orientation. To the extent that social entrepreneurs rely on systems or frameworks of shared meaning, their entrepreneurial initiatives can be regarded as being culturally as well as cognitively embedded not only within their local communities but also within the transnational communities of practice or professional communities to which they belong. Thus, the challenge will be to analyze the interactions between the institutional influences stemming from these different communities and the creation of new institutions within these communities. Embeddedness provides social entrepreneurs with an interesting dilemma - how to manage the benefits of local embeddedness with the pressures to scale and diffuse their work beyond local boundaries.

To address this question, it is necessary to understand when institutional pressures stemming from the local communities are more influential than the ones stemming from the other types of communities within which SEOs are embedded, and vice versa. This issue is a central one not only within the framework of the social entrepreneurship literature but also within the framework of the institutional theory literature, as we need to better understand how organizations deal with the tensions between the local and global contexts within which they are simultaneously embedded (Sorge, 2005).

Finally, this paper opens a number of new paths of research. First, it calls for empirical studies analyzing the influence of the institutional environment on SEOs and further examining their different strategic orientations. Are the three strategic orientations that we distinguish in this paper the only ones that SEOs may adopt? Do SEOs change their strategic orientation over time? Do they operate from several different strategic orientations concurrently? If so, why and how? Second, while we focus in this paper on the influence of the institutional context in which SEOs are embedded, on their likelihood of emergence and on their likelihood of adoption of certain strategic orientations, future research will need to account for the possible influence of other factors, such as founders' background and motivation (Baron, Hannan, and Burton, 1999a, 1999b, 2001; Burton, 1995). Addressing these issues and thereby better understanding the conditions of emergence and development of SEOs is crucial at a time when SEOs appear as a possible alternative and/or complement to the action of existing public and private organizations aimed at addressing social needs.

We also wish to articulate several shortcomings of this paper. We have not paid systematic attention to a number of important mechanisms arising from contextual differences such as those between perspectives of absolute poverty in underdeveloped countries and relative poverty in developed countries. Most of the examples in this paper implicitly address the notion of absolute poverty. A further crucial differentiation that future research will need to address is that between SEOs emerging organically from within communities, i.e., those which are "naturally" embedded or SEOs whose founders are external to the community and need to become embedded as a prerequisite to building a robust and sustainable SEO. In this paper, we largely employed the latter perspective in the selection of illustrative examples. We feel that this avenue is fruitful for understanding variation in and across communities. Emergence of "organic" SEOs in poor communities requires an explanation of why and how some community members can escape structural institutional pressures that otherwise recreate poverty for the rest of the community. That explanation would also need to include an inquiry into the sources and types of variation in the characteristics and relations between structure and agency at the levels of individuals and the collective. 


\section{References}

Abouleish, I. (2004), “Die SEKEM - Vision,” Mayer Verlag, Stuttgart.

Alvarez, S.A. and Barney, J. (2007), "Discovery and creation: Alternative theories of entrepreneurial action," Strategic Entrepreneurship Journal, Vol. 1, Nos 1-2, pp. 11-26.

Alvord, S.H., Brown, L.D., and Letts. C.W. (2004), "Entrepreneurship and societal transformation: An exploratory study," The Journal of Applied Behavioral Science, Vol. 40, No. 30, pp. 260-282.

Anderson, B. (1983), "Imagined communities: Reflections on the origin and spread of Nationalism," Verso, London.

Anteby, M., Battilana, J., and Pache, A.-C. (2007), "Marie Trellu-Kane at Unis-Cite," Harvard Business School Case, Harvard University Press, Cambridge, MA.

Austin, J., Stevenson, H., and Wei-Skillern, J. (2006), "Social and commercial entrepreneurship: Same, different, or both?," Entrepreneurship Theory and Practice, Vol. 30, No. 1, pp. 1-22.

Bagnasco, A. (1995), "Introduction: An unexpected and controversial return," in A. Bagnasco and C. F. Sabel (eds.), "Small and medium-size enterprises," Pinter, London, pp. 1-14.

Baker, T. and Nelson, R.E. (2005), "Creating something from nothing: Resource construction through entrepreneurial bricolage,” Administrative Science Quarterly, Vol. 50, No. 3, pp. 329-366.

Baker, T., Gedajlovic, E., and Lubatkin, M. (2005), “A framework for comparing entrepreneurial processes across nations," Journal of International Business Studies, Vol. 36, pp. 492-504.

Barley, S.R. and Tolbert, P.S. (1997), "Institutionalization and structuration: Studying the links between action and institution," Organizational Studies, Vol. 18, No. 1, pp. 93-117.

Baron, J.N., Hannan, M.T., and Burton, M.D. (1999a), "Building the iron cage: Determinants of managerial intensity in the early years of organizations," American Sociological Review, Vol. 64, pp. 527-547.

Baron, J.N., Hannan, M.T., and Burton, M.D. (1999b), "Engineering bureaucracy: The genesis of formal policies, positions, and structures in high-technology firms," Journal of Law, Economics, and Organization, Vol. 15, No. 1, pp. 1-41.

Baron, J.N., Hannan, M.T., and Burton, M.D. (2001), "Labor pains: Change in organizational models and employee turnover in young, high-tech firms," American Journal of Sociology, Vol. 106, No. 4, pp. 960-1012.

Bradach, J. (2003), "Going to scale: The challenge of replicating social programs," Stanford Social Innovation Review, Vol. 1, pp. 19-25.

Burt, R. (2001), "The social capital of structural holes," in M.F. Guillén and R.Collins (eds.), New Directions in Economic Sociology. Russell Sage Foundation, New York.

Burton, M.D. (1995), "The evolution of employment systems in high technology firms", Unpublished PhD dissertation, Stanford University. 
Calhoun, C. (ed.) (2001), “Oxford Dictionary of the Social Sciences," Oxford University Press, Oxford.

Chen, S. and Ravallion, M. (2007), "Absolute poverty measures for the developing world, 19812004," Proceedings of the National Academy of Sciences, Vol. 104, No. 43, pp. 16,757-16,762.

Coleman, J.S. ( 1988), "Social capital in the creation of human-capital," American Journal of Sociology, Vol. 94, pp. S95-S120.

Dacin, M.T., Dacin, P.A., and Matear, M. (2007), "Understanding social entrepreneurship: The intersection of cultural, social, and institutional resources," Paper presented at the Administrative Sciences Association Annual Meeting, Ottawa.

Dacin, T., Ventresca, M., and Beal, B. (1999), "The embeddedness of organizations: dialogue and directions," Journal of Management, Vol. 25, No. 3, pp. 317-56.

Dees, G. J., Battle Anderson, B., and Wei-Skillern, J. (2004), "Scaling social impact: Strategies for spreading social innovations," Stanford Social Innovation Review, Spring, pp. 24-32.

Defourny, J. (2001), "Introduction: From third sector to social enterprise," in C. Borzaga and J. Defourny (eds.), "The Emergence of Social Enterprise," Routledge, London.

DiMaggio, P. J. and Powell, W.W. (1983), "The iron cage revisited: Institutional isomorphism and collective rationality in organizational fields," American Sociological Review, Vol. 48, No. 2, pp. 147-160.

Dorado, S. (2006), "Social entrepreneurial ventures: Different values so different propositions of creation, no?," Journal of Development Entrepreneurship, Vol. 11, No. 4, pp. 319-343.

Easterly, W. (2006), “The White Man's Burden: Why the West's Efforts to Aid the Rest Have Done So Much Ill and So Little Good," Oxford University Press, Oxford.

Evans, P. (1995), "Embedded Autonomy: States and Industrial Transformation," Princeton University Press, Princeton.

Fowler, A. (2000), "NGDOs as a moment in history: Beyond aid to social entrepreneurship or civic innovation?,” Third World Quarterly, Vol. 21, No. 4, pp. 637-654.

Fowler, S.F., Lawrence, T.B., and Morse, E.A. (2004), "Virtually embedded ties," Journal of Management, Vol. 30, pp. 647-666.

Galaskiewicz, J. (1991),"Making corporate actors accountable: Institution-building in Minneapolis-St. Paul," in W.W. Powell and P.J. DiMaggio (eds.), "The new institutionalism in organizational analysis," University of Chicago Press, Chicago, pp. 293-310.

Galaskiewicz, J. (1997), “An urban grants economy revisited: Corporate charitable contributions in the Twin Cities, 1979-81, 1987-89,” Administrative Science Quarterly, Vol. 42, pp. 445-471.

George, G. and Prabhu, G. (2000), "Developmental financial institutions as technology policy instruments: Implications for innovation and entrepreneurship in emerging economies," Research Policy, Vol. 32, No. 1, pp. 89-108.

Global Entrepreneurship Monitor (2010), "Global comparison of social entrepreneurship," in N. Bosma and J, Levie (eds.), 2009 Global Report, Pinter, London, pp. 44-51. 
Greenwood, R., Diaz, A.M., Li, S., and Lorente, J.C. (2007), "Adapting to institutional complexity: The response of Spanish firms in the post-Franco era," Working Paper, University of Alberta.

Hirsch, P.M. and Levin, D.Z. (1999), "Umbrella advocates versus validity police: a life-cycle model," Organization Science, Vol. 10, No. 2, pp. 199-212.

Hitt, M.A., Dacin, T., Tyler, B., and Park, D. (1997), "Understanding the differences in Korean and U.S. executives' strategic orientations," Strategic Management Journal, Vol. 18, No. 2, pp. 159-167.

Hockerts, K. (2006), "Entrepreneurial opportunity in social purpose business ventures," in J. Mair, J. Robinson, and K. Hockerts (eds.), "Social Entrepreneurship," Vol. 1, Palgrave Macmillan, Basingstoke, pp. 142-154.

Jack, S.L. and Anderson, A.R. (2002), "The effects of embeddedness on the entrepreneurial process," Journal of Business Venturing, Vol. 17, No. 5, pp. 467-487.

Jansson, T. (2001), "Microfinance: From village to Wall Street," Working Paper, Inter-American Development Bank, Sustainable Development Department.

Johannisson, B. and Nilsson, A. (1989), "Community entrepreneurship - networking for local development," Journal of Entrepreneurship \& Regional Development, Vol. 1, No. 1, pp. 1-19.

Kerlin, J. (2006), "Social enterprise in the United States and Europe: Understanding and learning from the differences," Voluntas, Vol. 17, No. 3, pp. 247-263.

Knight, F.H. (1921), “Risk, Uncertainty and Profit,” Harper, New York.

Krackhardt, D. and Kilduff, M. (2002), "Structure, culture and Simmelian ties in entrepreneurial firms,” Social Networks, Vol. 24, No. 3, pp. 279-290.

Lawson, T. (2003), “Reorienting Economics,” Routledge, London.

Mair, J. and Martí, I. (2006), "Social entrepreneurship research: A source of explanation, prediction, and delight," Journal of World Business, Vol. 41, No. 1, pp. 36-44.

Mair, J. and Martí, I. (2009), "Entrepreneurship in and around institutional voids: A case study from Bangladesh," Journal of Business Venturing, Vol. 24, No. 5, pp. 419-435.

Mair, J. and Seelos, C. (2006), “Digital democracy”, European Business Forum, Vol. 26, pp. 59-61.

Mair, J., Martí, I., and Ganly, K. (2007), "Institutional voids as spaces of opportunity," European Business Forum, Vol. 31, pp. 34-39.

Marquis, C. (2003), "The pressure of the past: Network imprinting in intercorporate communities," Administrative Science Quarterly, Vol. 48, pp. 655-689.

Marquis, C. and Battilana, J. (2009), "Acting globally but thinking locally? The enduring influence of local communities on organizations," Research in Organizational Behavior. Vol. 29, pp. 283-302.

Marquis, C. and Lounsbury, M. (2007), "Vive la resistance: Consolidation and community level professional counter-mobilization in US banking," Academy of Management Journal, Vol. 50, No. 4, pp. 799-820. 
Marquis, C., Glynn, M.A., and Davis, G.F. (2007), “Community isomorphism and corporate social action," Academy of Management Review, Vol. 32, pp. 925-945.

Martí, I. and Mair, J. (2009), "Bringing change into the lives of the poor: Entrepreneurship outside traditional boundaries," in Lawrence, T., Suddaby, R. and Leca B. (eds.), “Institutional Work," Cambridge University Press, Cambridge, pp. 92-119.

Martorana, P.V., Galinsky, A.D., and Rao, H. (2005), "From system justification to system condemnation: Antecedents of attempts to change status hierarchies," in M.A. Neale, E.A., Mannix and M. Thomas-Hunt (eds.), Research on Managing Groups and Teams," Status, Vol. 7, Jai Press, Greenwich, CT, pp. 283-313.

Mizzau, L. and Montanari, F. (2008), "Cultural districts and the challenge of authenticity: The case of Piedmont, Italy,” Journal of Economic Geography, Vol. 8, pp. 651-673.

Moran, P. and Ghoshal, S. (1999), "Markets, firms, and the process of economic development," Academy of Management Review, Vol. 24, pp. 390-412.

Morse, E.A., Fowler, S.F., and Lawrence, T.B. (2007), "The impact of virtual embeddedness on new venture survival," Entrepreneurship Theory and Practice, Vol 31, No. 2, pp. 139-159.

North, D. C. (1990), "Institutions, institutional change and economic performance," Cambridge University Press, Cambridge.

OECD (2009), "Development aid at its highest level ever in 2008," OECD Newsroom, 30 March 2009.

Pache, A. C. and Chalencon, G. (2007), "Changer d'échelle: Vers une typologie des stratégies d'expansion géographique des entreprises sociales," Revue Internationale des Etudes Coopératives, Mutualistes et Associatives, Recma.

Pawson, R. and Tilley, N. (1997), "Realistic Evaluation,” Sage, London.

Penrose, E. (1959), “The Theory of the Growth of the Firm," John Wiley and Sons, New York.

Peredo, A.M. and Chrisman, J.J. (2006), "Toward a theory of community-based enterprise," Academy of Management Review, Vol. 31, No. 2, pp. 309-328.

Perrini, F., Vurro, C., and Costanzo, L. (2008), "Developing an interactive model of SE: Opportunity discovery and exploitation in the case of San Patrignano," Working Paper, Università Bocconi, Italy.

Portes, A. and Sensenbrenner, J. (1993), "Embeddedness and immigration: Notes on the social determinants of economic action," American Journal of Sociology, Vol. 98, No. 6, pp. 13201350.

Reger, R.K. and Huff, A.S. (1993), "Strategic groups: A cognitive perspective," Strategic Management Journal, Vol. 14, pp. 103-124.

Rodrik, D. (2007), "One economics, many recipes: Globalization, institutions, and economic growth,” Princeton University Press, New Jersey. 
Sabel, C.F. (1989), "Flexible specialization and the re-emergence of regional economies," in P. Hirst and J. Zeitlin (eds.), "Reversing Industrial Decline. Industrial Structure and Policy in Britain and Her Competitors," Berg Publishers, Oxford.

Scott, A. and Storper, M. (2003), "Regions, globalization, development," Regional Studies, Vol. 37, No. 6-7, pp. 579-593.

Scott, W.R. (2001),” Institutions and Organizations,” Sage, Thousand Oaks, CA.

Seelos, C. and Mair, J. (2005), "Social entrepreneurship: Creating new business models to serve the poor," Business Horizons, Vol. 48, No. 3, pp. 241-246.

Seelos, C. and Mair, J. (2007), "Profitable business models and market creation in the context of deep poverty: A strategic view,” Academy of Management Perspectives, Vol. 21, pp. 49-63.

Seelos, C. and Mair, J. (2009), "Hope for sustainable development: How social entrepreneurs make it happen," in Ziegler, R. (ed.), "An Introduction to Social Entrepreneurship: Voices, Preconditions and Contexts, Edward Elgar, Cheltenham, pp. 228-245.

Seelos, C. and Mair. J. (2010), "Organizational mechanisms of inclusive growth: A critical realist perspective on scaling,” Working Paper WP-840, IESE Business School, Barcelona.

Short, J.C., Moss, T.W., and Lumpkin, G.T. (2009), "Research in social entrepreneurship: Past contributions and future opportunities," Strategic Entrepreneurship Journal, Vol. 3, pp. 161-194.

Sorge, A. (2005), "The global and the local: Understanding the dialectics of business systems," Oxford University Press, Oxford.

Stark, D. (1996), "Recombinant property in East European capitalism," American Journal of Sociology, Vol. 101, No. 4, pp. 993-1027.

The World Bank (1990), “World Development Report: 1990," Oxford University Press, New York.

Tönnies, F. (1963) [1887], “Community and Society (Gemeinschaft und Gesellschaft)," translated and edited by Charles P. Looomis, Harper \& Row, New York.

Tracey, P. and Jarvis, 0. (2007), "Toward a theory of social venture franchising," Entrepreneurship Theory and Practice, Vol. 31, No. 5, pp. 667-685.

Trigilia, C. (1995), "A tale of two districts: Work and politics in the third Italy," in A. Bagnasco and C. F. Sabel (eds.), "Small and medium-size enterprises," Pinter, London, pp. 31-50.

Tsoukas, H. (1989), "The validity of idiographic research explanations," Academy of Management Review, Vol. 14, pp. 551-561.

Uzzi, B. (1996), "The sources and consequences of embeddedness for the economic performance of organizations: The network effect," American Sociological Review, Vol. 61, pp. 674-698.

Uzzi, B. (1997), "Social structure and competition in interfirm networks: the paradox of embeddedness," Administration Science Quarterly, Vol 42, No. 1, pp. 35-68.

Walsh, J. (1995), "Managerial and organizational cognition: A trip down memory lane," Organization Science, Vol. 6, pp. 280-321. 
Weber, M. (1904), “Max Weber on the Methodology of the Social Sciences," The Free Press, Glencoe, IL.

Woolcock, M. and Narayan, D. (2000), "Social capital: Implications for development theory, research, and policy," The World Bank Research Observer, Vol. 15, pp. 225-249.

Woolcock, M. (1998), "Social capital and economic development: Towards a theoretical synthesis and policy framework,” Theory and Society, Vol. 27, pp. 151-208.

Yunus, M. (2007), "Creating a World Without Poverty: Social Business and the Future of Capitalism,” Public Affairs, Philadelphia.

Zahra, S.A., Gedajlovic, E., Neubaum, D.O., and Shulman, J.M. (2009), “A typology of social entrepreneurs: Motives, search processes and ethical challenges," Journal of Business Venturing, Vol. 24, No. 5, pp. 519-532.

Zahra, S.A., Rawhouser, H., Bhawe, N., Neubaum, D.O., and Hayton, J.C. (2008), "Globalization of social entrepreneurship opportunities," Strategic Entrepreneurship Journal, Vol. 2, No. 2, pp. 117-131. 